Article

\title{
The European Parliament and the Layered Politicization of the External Dimension of the Common Fisheries Policy
}

\author{
Hubert Zimmermann \\ Institute for Political Science, Philipps University Marburg, 35036 Marburg, Germany; \\ E-Mail: zimmer2d@staff.uni-marburg.de
}

Submitted: 4 April 2019 | Accepted: 6 August 2019 | Published: 27 September 2019

\begin{abstract}
When the Lisbon Treaty entered into effect, the European Parliament became a core player in the decision-making processes of the EU's Common Fisheries Policy (CFP) and its external dimensions. This new role suggested a shift towards stronger politicization in what had previously been a rather technocratic policy field. However, the CFP is not yet marked by a clear and consistent level of politicization. I use the concept of 'layered politicization' to explain this pattern. Although it is not comparable to the degree of political controversy shaping fully politicized policy fields, some similar political dynamics can be observed. Among them is a transformation in the policy process due to higher ratification requirements; a higher likelihood of political deadlock resulting from an increasing number of veto-players; and a strengthening of the contested legitimacy of EU decision-making. An empirical test of these theoretical propositions is provided here in the form of two case studies; the negotiation of Fisheries Partnership Agreements with Morocco and Mauritania.
\end{abstract}

\section{Keywords}

common fisheries policy, European Parliament, fisheries partnership agreements, politicization

\section{Issue}

This article is part of the issue "Out of the Shadows, Into the Limelight: Parliaments and Politicisation", edited by Christine Neuhold (Maastricht University, The Netherlands) and Guri Rosén (University of Oslo, Norway).

(C) 2019 by the author; licensee Cogitatio (Lisbon, Portugal). This article is licensed under a Creative Commons Attribution 4.0 International License (CC BY).

\section{Introduction}

Research on the EU's foreign economic policies has long focused mainly on the impact of the principal-agent dynamics between the European Commission (EC) and the Council, the influence of commercial lobby groups, and the efficiency of EU negotiating strategies. To be sure, concerns about input-and output-legitimacy often provided an implicit background theme to these studies. And yet, in recent years, the elevated level of societal contestation and political controversy reached by debates over EU foreign economic policy, particularly trade policy, has been rather unexpected. As detailed in this special issue, the burgeoning power of the European Parliament (EP) over the past decade has significantly extended the potential for societal contestation, far beyond the situation which existed when the Council and the EC still reigned supreme in foreign economic policy.
The EP has become a focal point for research on this phenomenon, which is usually described as a process of politicization of EU politics.

Politicization as a concept has been used with increasing frequency to analyze heightened political conflict and public controversy in many EU-related policy fields. But there remains an open question; can we also use this concept of politicization to analyze issues that are not as visible on the public radar and not as prominent on the parliamentary agenda as, for example, Transatlantic Trade and Investment Partnership (TTIP) or Comprehensive Economic and Trade Agreement, even though the EP has been empowered in a very similar way in these less prominent areas (Rosén, 2016)?

Indeed, as De Bièvre and Poletti (2019) have shown, many lower profile trade negotiations generate hardly any public contestation. Hutter, Kriesi and Grande (2016, p. 280) talk about "punctuated politicization" which 
varies across time, context and country. Hurrelmann, Gora and Wagner maintain that "only the most fundamental aspects of European integration...are politicized in the population, while the EU's policy-making activities remain largely non-salient" $(2015$, p. 44$)$. But is this also true for the recently parliamentarized Common Fisheries Policy (CFP) of the EU and its external dimensions? Can we nonetheless speak of politicization in this area, bearing in mind that the June 2019 European elections strikingly demonstrated the salience of environmental concerns for European politics? If so, what does such a pattern of politicization look like? These are the questions this article seeks to answer.

I will first trace the extent of politicization in the CFP, specifically in its external dimension. I will then propose the concept of 'layered politicization' to deal with a pattern of politicization that is incomplete and less comprehensive than is the case in the usual empirical studies of politicization (e.g., European integration per se, EU trade policy or European migration policies). Specifically, I will look at the role the EP played in causing this pattern. Finally, I will examine EU external fisheries policies through an analysis of so-called Sustainable Fisheries Partnership Agreements (SFPAs) and discuss the effects of this layered form of politicization.

There is a substantial literature on how to define politicization in a given policy field. For De Wilde, Leupold and Schmidtke (2016) politicization consists of three elements: (i) the growing salience and visibility of a policy, (ii) an increasing polarization of opinions in this field, and (iii) an expansion of the number of actors and audiences involved in decision-making processes related to this policy (for a similar conceptualization, see Hutter, Kriesi, \& Grande, 2016, p. 8). Essentially, then, politicization refers to a situation in which a policy field that was previously subject to almost exclusively technocratic and elite-driven policy making with limited public controversy becomes the subject of public debate and polarization (De Wilde et al., 2016).

A number of scenarios can give rise to politicization. These include civil society groups and (often forgotten) commercial groups vigorously taking up a particular topic in an attempt to win strong public attention; political parties making the issue part of their platforms (Hooghe \& Marks, 2009, pp. 18-19); and mainstream media outlets regularly publishing on the topic. In this way, a policy which was previously characterized by an insider discourse, insider bargaining and insider dealings without public debate is transformed.

Inevitably, however, this definition begs the question as to when the threshold is reached at which a previously non-politicized issue becomes politicized. As noted by, for example, Faber and Orbie (2007), trade policy making always involved a variety of actors and was debated intensively among them. It is also possible that some aspects of an issue are contested strongly (see the investorstate dispute settlement in TTIP), whereas the bulk of it is still dealt with behind closed doors.
Such an uneven pattern of politicization also seems to characterize the CFP and its external dimensions. The CFP is certainly not an issue that regularly captures the headlines. At the same time, it has undoubtedly become more controversial and, despite the comprehensive 2013 reform, it usually has a negative press. A substantial number of environmental NGOs have become active in this area, while highly successful documentaries have highlighted the parlous state of the marine environment. It is usually in such contexts that the CFP is targeted.

To establish a measure of the politicization of the CFP, I will use the three generally accepted dimensions of politicization mentioned above (salience, polarization, mobilization). I will trace the development of the CFP with respect to these three factors, paying particular attention to its external dimension. As we shall see, this analysis reveals a hybrid pattern of politicization, which I try to capture with the concept of 'layered politicization'. I will also briefly discuss the effects of this development. The existing literature has generally identified two broad sets of consequences of politicization. Zürn (2014, pp. 58-59) and others have stated that politicized policy fields are less prone to being captured by special interests, and are more responsive to broader societal concerns and diffuse interests. This imposes losses on particular lobbies, leading to more transparency and better access for societal groups. Conversely, the more problematic consequences of politicization include less efficient policy-making in terms of output, with a significantly higher rate of ratification failures (Hooghe \& Marks, 2009). Can these effects also be observed in a (partially) politicized CFP?

\subsection{Research Design and Data}

The politicization literature has employed a variety of methods to measure politicization in a given policy field. Scholars have examined the reflection of politicized EU policies in party manifestos (De Vries \& Hobolt, 2015; Hooghe \& Marks, 2018), the activities of lobby organizations (Dür \& Mateo, 2016), the intensity of mass media debates (for example, Hutter et al., 2016; Schmidtke, 2016), and trends in public opinion research (Hurrelmann, Gora, \& Wagner, 2015).

This research has analyzed some of the most common indicators of politicization over time. I measured the salience of EU fisheries policy by tracing its prominence in national newspapers from four of the largest member states, three of which are home to large fishing industries (i.e., France, Spain and the UK; Germany is the fourth country). Articles were searched in the respective languages on whether they mentioned the CFP or elements of the external dimension of EU fisheries policies, such as partnership agreements. Party manifestos of party groups in the EP prior to the 2019 elections were investigated for evidence of heightened concern with fisheries policies. The expansion of actors was traced through a review of the evolution of the CFP, with a focus on exter- 
nal governance, and through an analysis of the involvement of new actors in decision-making. This also testifies to a measure of polarization, because it shows how a relatively closely-knit community of decision-makers in fisheries policies has greatly expanded over time.

The case studies themselves are based on a detailed tracing of the negotiation processes, primarily through a comprehensive analysis of official documents from all major EU institutions involved in the negotiations, as well as from specialized agencies, evaluations by think-tanks and NGOs, and press articles. Some open questions were clarified in confidential interviews with a high-ranking official from the EU's Directorate-General for Maritime Affairs and Fisheries (DG Mare).

\section{Politicization of Fisheries Policy in the EU?}

For decades, fisheries have been a neglected aspect of European integration. Even today, it has almost no place in most textbooks on the EU. Indeed, the CFP was barely mentioned in the Rome treaties. It was initially considered part of the Common Agricultural Policy (CAP), and thus subject to supranational governance. Only with the accession to the European Community of important fishing nations, such as the UK, Spain or Portugal, did fisheries become an issue of concern for European politics.

The principles of the CAP were used in the first fisheries regulations. They provided for a common market in fisheries products and structural aid for fishing regions (Penas Lado, 2016, p. 22). The external dimension of EU fishing policy was even more sparsely regulated, and there were few rules that governed the activities of EU vessels. In 1982, however, the United Nations Convention on the Law of the Sea was signed into effect. This law gave marine states jurisdiction over an Exclusive Economic Zone (EEZ) that stretched 200 nautical miles from the shoreline. Partly as a reaction, the EU formally adopted the CFP in 1983. About a quarter of the fish taken by EU vessels came from waters outside the EU, which lent a vital importance to international policies and agreements. Since the 1990s, the EU has intensified the external dimension of its fisheries policy by negotiating access rights via so-called partnership agreements and by participating in international fisheries management organizations.

The early CFP was governed by a marine-industrial complex in which the distribution of quotas and the writing of complicated regulations was negotiated behind closed doors (Lövin, 2012; Wakefield, 2016, pp. 55-57). This process was dominated by the core fishing nations of the EU in the Council, particularly Spain and France. Big sector organizations like Europêche and the French and Spanish fisheries organizations with their permanent representatives in Brussels exerted a strong influence through lobbying, much as influential agricultural groups had in the CAP (Griffin, 2013; Payne, 2000). Scientific advice was requested, but the recommendations were usually disregarded (Daw \& Gray, 2005).
To be sure, there have been a few flare-ups, such as the Cod Wars between the UK and Iceland in the mid1970s and the Spanish-Canadian turbot war of 1994-96. Generally, however, the execution of the CFP at the EU-level was characterized by low public salience and was subject to control by a limited number of decision makers (Penas Lado, 2016, pp. 275-276). Conflicts were usually dealt with in the Council without significant public involvement. Protests against the CFP were highly concentrated in local fishing communities that felt disadvantaged by EU regulations, such as Scottish fishermen (a constituency which, predictably enough, voted for Brexit). Despite clear signs of mismanagement and unsustainable exploitation, no substantial changes occurred until the turn of the millennium. It was at this point that the environmental consequences of overfishing became glaringly obvious (Penas Lado, 2016, pp. 232-249).

In 2002, these grave problems were acknowledged for the first time by a comprehensive CFP reform. The agent of this new emphasis on sustainability was not the public but rather the EC. Certainly, this new-found enthusiasm clearly reflected the rise of environmental parties and civil society organizations within the EU. Starting with the reform of 2002, the EU claimed to switch the focus of its agreements with foreign partners. The latter were now re-branded as fisheries partnership agreements (FPAs), replacing a pure concern with access rights to a broader agenda encompassing structural and logistical aid for partner countries as well as environmental considerations (Witbooi, 2008; Witbooi, 2012). The reform also created so-called Regional Advisory Councils to allow for a greater involvement of diverse stakeholders. The narrative of the negotiations changed substantially and the number of involved actors increased. However, the actual content of the agreements and the activities of the EU fishing industry did not yet reflect this (Daw \& Gray, 2005; Gegout, 2016).

Thus, despite the reform, complaints by NGOs and scientists about the exploitation of the seas and the role of the EU became stronger, and public alarm grew accordingly. The EC sought to present itself as a progressive force, which resulted in 2009 in the publication of a Green Paper (EC, 2009). A public debate on the proposals was initiated, which generated 394 responses mostly from industry and the general public. 63 statements by civil society organizations and 65 from national or regional governments were received (EC, 2010).

On 1 January 2014, a comprehensive CFP reform went into effect. This reform stressed the normative dimension of fisheries policies. The FPAs were renamed SFPAs. The reform process was decisively shaped by the new range of actors who weighed in on the debate. For example, numerous NGOs seized on the opportunity provided by the Ocean 2012 coalition, which united 193 groups in 24 member countries. Most importantly, however, the Lisbon Treaty empowered the EP by giving it co-decision making powers in the CFP, which en- 
compassed the external dimension. Due to this development, any agreement in this area now requires the EP's endorsement according to the consent procedure (that is, after a single reading, the EP is given the option to accept or reject the results, but not to amend them). Prior to the vote in the plenary, the EP Fisheries Committee (PECH) discusses the draft agreement and gives its opinion. In recent years, there were often sharp divisions within the Committee. Other EP Committees, in particular those on Development and the Budget, usually also discuss the draft agreement and recommend approval or disapproval. Once the EP gives its consent, the Council can ratify the agreement. As in trade policy, both the EP and the Council have veto power when it comes to the ratification of agreements.

After the Lisbon Treaty was ratified, the EP immediately became very active in fisheries policy. Greene and Cross $(2015$, p. 8) found that plenary speeches by MEPs on CFP topics rose strongly after the Green Paper was published by the EC. In a 2012 resolution on the external dimension of the CFP, the EP called on the EC to negotiate not with the main objective of "obtaining fishing rights for EU vessels but [rather]...with the aim of attaining comparable sustainable management rules as the EU in the third partner country" (EP, 2012). And indeed, regulation 1380/2013 of December 11, 2013, which codifies the reformed CFP, essentially comprises a statement by the Council and the EP stressing their commitment to such objectives in partnership agreements (EP \& Council of the European Union, 2013). The long deliberative process of the reform firmly entrenched sustainability as the dominant discourse in the EU'S CFP. This also reflected public opinion in most EU countries (see, for example, Client Earth, 2018).

Given this external normative pressure, the EC began to closely coordinate negotiations with the EP
(Zimmermann, 2016) and systematically tried to enlist the EP's legitimation resources (see Rosén, 2016). The Lisbon Treaty thus ensured that rules guiding decisionmaking involved many diverse actors. The formerly technocratic decision-making process that had characterized this policy field was thus severely compromised. The emergence of the EP as a key player gave many actors a new forum to make their voices heard.

Despite all of this, the CFP and its external dimensions only partially exhibit the characteristics of a politicized policy field. There is clearly a continuous expansion of relevant actors in the decision-making process (criterium iii) and there are sharp divisions among them, with the attendant strong contestation of the CFP and its components (criterium ii). However, the public salience of the issue (criterium i) remains rather limited.

This is substantiated by a comprehensive search in the media regarding the public attention garnered by the CFP over the past twenty years (that is, the approximate time period in which public contestation of European fisheries policies began to extend beyond the confines of regional fisheries communities). A Nexis search of English, German, French and Spanish language newspapers showed that the CFP was not very frequently the object of articles. This pattern remained constant until 2016, though there was a small spike during the debate about the CFP reform. The precipitous rise in Englishlanguage papers after 2016 is due to Brexit, particularly the widely reported protest activity of Brexit campaigners against the withdrawal deal with the EU. This culminated in the dumping of dead fish into the Thames by Nigel Farage and his co-campaigners. Given the much higher number of British papers in the database, British published opinion is over-represented (Figure 1).

The same trend is visible if one searches the same terms in selected 'quality' journals (Figure 2).

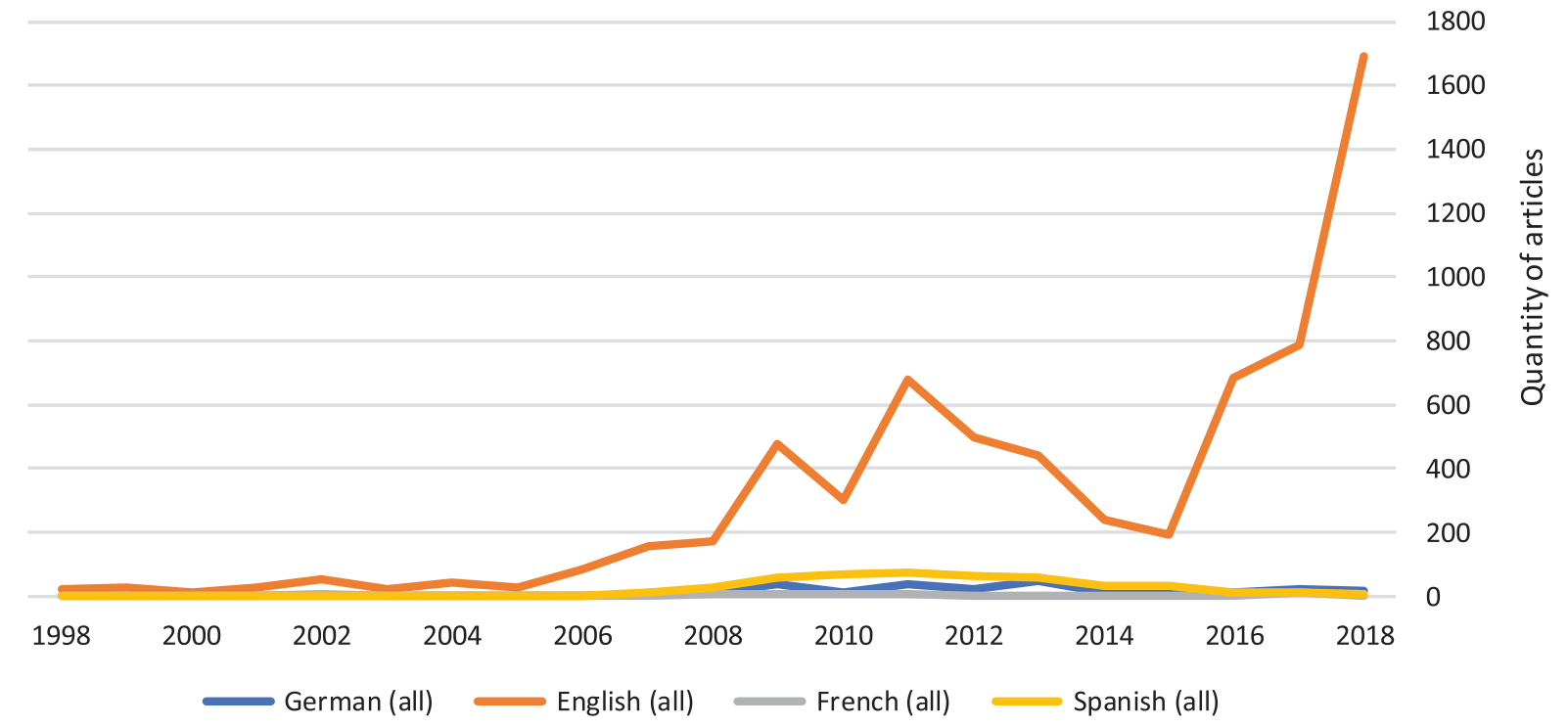

Figure 1. Search in Nexis Database of about 2300 European newspapers (among those 211 German, 211 French, 1113 British, 61 Spanish). Search Terms: Common Fisheries Policy, EU Fisheries Policy, European Union + Fisheries Policies (and translations of these terms in German, French and Spanish). 


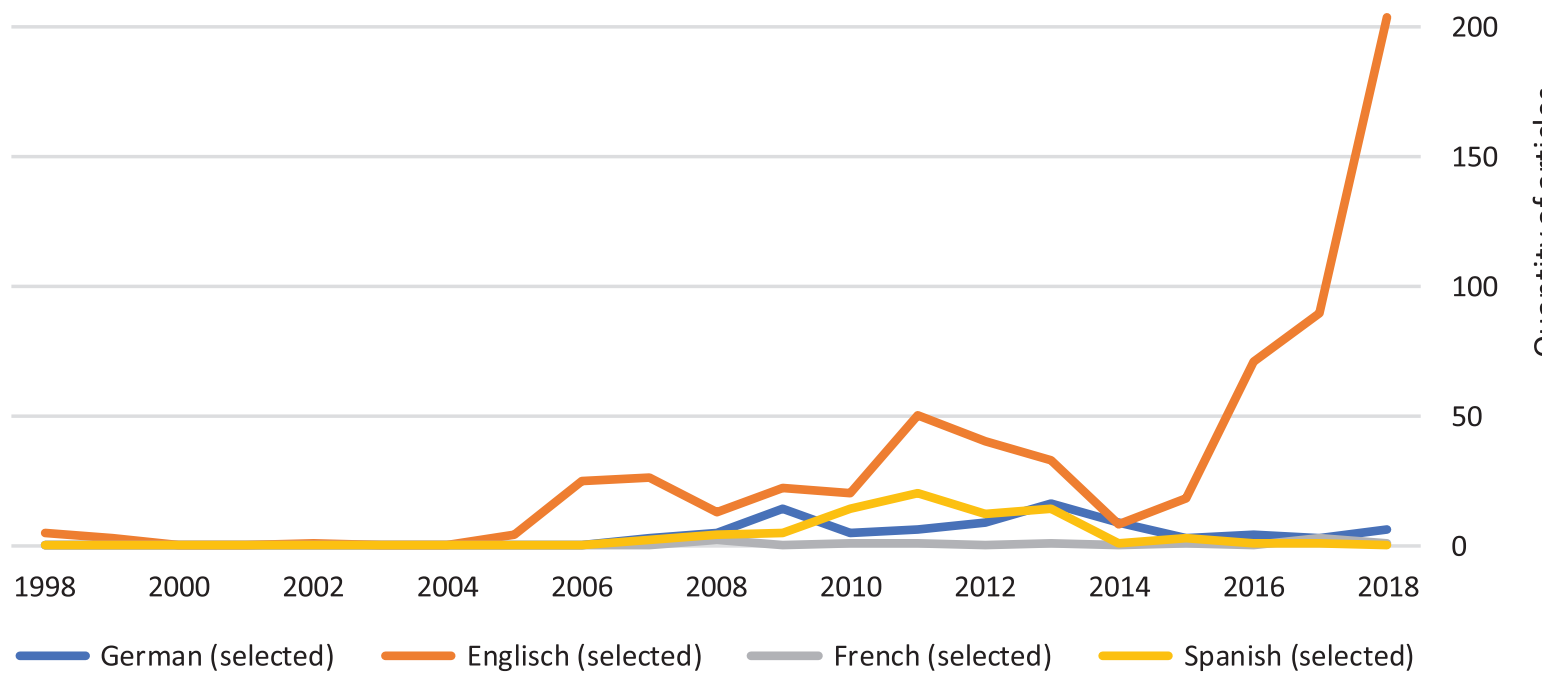

Figure 2. Search in Nexis Database on Selected Newspapers. German (Tagesspiegel, taz, die tageszeitung, Die Welt, Die ZEIT, Welt am Sonntag); English (The Daily Telegraph, The Guardian, Daily Mail, The Daily Mail and Mail on Sunday); French (Le Monde, Le Figaro, Le Figaro Online); Spanish (EI Pais, El Mundo). Search terms are the same as in Figure 1.

Overall, then, there seems to be no sustained public debate in EU countries on fisheries, at least not one that is reflected in newspapers.

The same pattern emerges from an examination of the manifestos of the party groups of the EP. Only the Greens and the Left briefly mentioned fisheries in their 2019 manifestos. The overall picture remains rather unclear, suggesting very punctuated politicization. Does this mean that an analysis of the CFP and its external dimension through the lens of politicization will inevitably yield few benefits?

\section{The 'Layered Politicization' of the CFP}

This short review of the development of the CFP suggests that any use of the concept of politicization to analyse less prominent areas of EU external policies is problematic. Is there anything to be gained from using this concept to understand the dynamics in this policy field? I argue here that, with a more fine-grained conceptualization of politicization, we can still capture increasing contestation, and explain effects such as an increasing likelihood of ratification failure. One way to move towards this goal is to take into account recent advances in the literature on institutional change. This encompasses both the descriptive and prognostic dimensions of politicization (Rixen \& Viola, 2015; Streeck \& Thelen, 2005).

While many conceptualizations developed by the institutionalist literature are potentially useful, the recent framework presented by Lowndes and Roberts (2013) offers a good starting point. These authors see institutions as composed of three layers: narratives, rules and practices. This disaggregation makes institutions not only more intelligible; it also better helps us to understand their effects and their reaction to politicization (Lowndes \& Roberts, 2013, p. 63).

Summarizing briefly, narratives designate the most important discourses within an institution. Politicized narratives suggest a highly contested discourse with conflicting interpretations about correct policies. Lowndes and Roberts conceptualize rules as written clauses, regulations and laws. Such rules structure the political process. If the rules of decision-making have developed in such a way that they easily provoke intense political conflict and involve many potentially competing actors, we can speak of politicized rules. Finally, practices describe the conduct and policy-output of institutions. If the implementation of agreed policies is publicly contested, politicized practices can be observed.

In each of these three dimensions, the parliamentarization of the CFP might have resulted in substantial change. The involvement of the EP has given voice to new actors. These actors may look to influence decisionmaking by focusing directly on MEPs. Obviously, the layer of rules has also changed greatly due to the introduction of a new veto player.

Combining the three institutional layers with the dimensions of politicization cited by most of the relevant literature yields the following table:

This table suggests the possibility of an 'incomplete' or 'layered' politicization in which not all the boxes will be ticked. Narratives might be highly polarized and visible, whereas rules and practices might remain quite technocratic. It is also possible to imagine a policy field with a highly politicized narrative and mobilized rules (due to a wide array of actors), but which nonetheless fails to take 
Table 1. Layers of politicization.

\begin{tabular}{llll}
\hline \multirow{2}{*}{ Dimensions of politicization } & \multicolumn{3}{c}{ Layers of Institutions } \\
\cline { 2 - 4 } & \multicolumn{1}{c}{ Narratives } & Rules & Practices \\
\hline Salience/Visibility & Salient Narrative & Salient Rules & Salient Practice \\
\hline Polarization & Polarized Narrative & Polarized Rules & Polarized Practice \\
\hline Mobilization & Mobilized Narrative & Mobilized Rules & Mobilized Practice \\
\hline
\end{tabular}

on much broader salience, and therefore does not generate much media attention. This is apparently the case with the CFP.

Confronting this framework with the effects of politicization yields various propositions. For example, it is possible that, despite a politicized narrative, policy output remains technocratic. This might be the result of strongly path-dependent decision-making rules, or the empowerment of important veto-players. By contrast, thorough politicization would shape not only politicized narratives; it would also result in a process in which decisions are made in an openly political contest within politicized institutions (such as parliaments but not necessarily parliamentary committees). This would lead to practices and results that are different from those of a purely technocratic environment.

To detect layered politicization in the external dimension of the CFP, I will first trace the course of recent negotiations of important SFPAs. The aim is to establish whether or not these have become more controversial, in particular as a consequence of the involvement of the EP. Second, this will allow me to identify a potentially larger set of actors that are involved in the decisionmaking process. As in the first section of this article, a search on Nexis regarding the external dimension of the CFP has been undertaken. This resulted in almost no hits.

\section{Layered Politicization and SFPAs}

The EU has signed more than twenty bilateral agreements with third countries that deal with the access of EU vessels to the exclusive economic zones of these countries. The protocols governing these agreements are periodically renegotiated, with almost half of them currently dormant. The EU pays a fee for access, and the EU fishing industry is allowed to take the surplus yield. According to the EU, these agreements set the standard for international fisheries in terms of sustainability, benefits for the local population and transparency. Nonetheless, they are often depicted as exploitative. In the last decade, the overall contestation of some of the agreements has risen considerably. The following case studies use the framework established in the preceding paragraphs to trace this pattern of politicization and the role of the EP in this process. I will then assess the impact of politicization on the negotiation of SFPAs. As case studies, I have selected the EU fisheries agreements with Morocco and
Mauritania, as these are perhaps the most important and the most contested.

\subsection{Morocco}

Morocco was once a reliable fishing ground for the EU, particularly for Spanish and Portuguese vessels. Early fisheries agreements concluded in the 1980s and 1990s were uncontroversial. In 1999, however, Morocco refused to sign a new protocol, citing the exhaustion of fish stocks. Despite strong efforts by the EC, a follow-up protocol proved elusive until 2007. Following intense lobbying by the fishing industry, the EC finally presented a new draft agreement. This draft provoked some controversy in the Council. The reason was not the economic or environmental dimension of the protocol, but rather the very political problem of the inclusion of the waters of the Western Sahara. This territory, formerly occupied by Spain, has been governed by Morocco since 1975, against strong resistance by the local population. The EU is internally divided on whether Morocco's often brutally enforced annexation should be condoned. These divisions are clearly shown by the convoluted moniker given in EU official language to the region: a "non-self-governing territory 'de facto' administered by the Kingdom of Morocco".

And yet this unusual territory also includes the best fishing grounds (especially since Moroccan coastal waters are already quite empty). Many member states and NGOs (such as Fishelsewhere.com, founded in 2006 by Western Sahara activists) claim that the EU's FPAs implicitly recognize Morocco's sovereignty over the territory and lead to the exploitation of marine resources, to the detriment of the inhabitants of Western Sahara, the Saharawis. In 2007, Sweden voted against the EC's draft in the Council because of this problem. Other countries also voiced their concerns. Nonetheless, the protocol was ratified quite smoothly, reflecting a low level of public salience and a technocratic decision-making process that created only a few ripples within European public opinion.

In 2011, when the agreement was on the verge of expiration, Spain lobbied hard for an extension. However, scientific evaluations of the previous protocol gave its sustainability record a very poor rating (Oceanic Développement, 2010). The EC had recently published its Green Paper on the sorry state of the CFP. It thus tried 
to gain time for a new approach by requesting an extension for just one year. Even within the EC, opinions about a new agreement were divided: DG Mare argued that the waters of the Western Sahara should be excluded, while other DGs stressed the overall importance of relations with Morocco (Jönsson, 2012, p. 29). A similar division revealed itself within the Committee of Permanent Representatives, which prepares Council meetings.

Despite these divisions, the Council gave the EC a mandate to open negotiations in order to avoid a new disruption of EU fishing activities. On this basis, in February 2011, the EC quickly reached an agreement with the Moroccan government that included the Western Sahara. In June, the Council approved the result with a narrow majority. In December 2009, however, the Lisbon Treaty had entered into force, which meant that the EP was now required to give its consent. The PECH was still dominated by Spanish and French Representatives, and it sided with the EC and the Council. The Budget and Development Committees, however, recommended that the EP withhold its consent (Jönsson, 2012, p. 42).

Consequently, an intense debate developed in the parliament. The controversy over the self-determination of the Sawarahis, the ecological consequences of largescale fishing in Western African waters, and the developmental implications of the agreements became much more visible with the mobilization of the EP. Previously, this kind of polarized narrative had been stifled by technocratic rules. But now it came dramatically to the surface. What's more, critical groups suddenly had an institutional target beyond individual member states. Indeed, in December 2011, the plenary of the EP rejected an extension of the agreement on the grounds that the EC had not demonstrated its ecologically sustainability or economic viability, or that it would be beneficial to the Saharawis. The EP demanded that any new protocol should respect international law, that it should be sustainable, both in economic and ecological terms, and that the uses of EU funds should be made transparent (Passos, 2016, p. 93).

As a result of the EP vote, Morocco closed its fishing grounds to all EU vessels. After vociferous protests by the fishermen and the governments representing them, the Council authorized the EC to continue the talks and to push for an improved agreement, in particular with respect to the concerns expressed by the EP. The EC then drafted a new protocol with more detailed provisions on how the money would be distributed within Morocco, specifically to the Sawarahis (Interview with EC Official; $E P, 2013)$. The Council discussed the draft agreement in early November 2013. Sweden and Denmark voted against, while the UK, Netherlands and Finland abstained. This was enough for a qualified majority.

On 10 December 2013, after extensive and heated debate, the EP voted for the agreement with 310 votes against 204 no-votes and 49 abstentions. In its resolution, the EP demanded participation in the implementation of the agreement by, for example, sending observers to the EU-Moroccan joint committees set up by the protocol (EP, 2013a). Naturally, the fishing industry was delighted to gain access to Moroccan waters. But opponents of the agreement, such as the Greens in the EP and NGOs supporting the cause of the Saharawis, denounced the vote as shameful. The episode showed that rules and practices in the negotiation of this agreement had become polarized, and it demonstrated the increasing number of actors that were mobilized during the process of policy formulation. The days of a permissive consensus on the negotiation of fisheries agreements with Morocco were long gone.

The following years underlined this new reality. In 2014, the Frente Polisario, Western Sahara's liberation movement, launched a case at the European Court of Justice to contest a separate agreement on trade in agricultural products. In December 2015, the Court ruled that trade agreements with Morocco could not apply to the Western Sahara, causing Morocco to freeze its relations with the EU. The Council appealed against the decision and recently won the case (Court of Justice of the European Union, 2016). NGOs fighting for the recognition of the rights of the Sawarahis, however, were emboldened. They challenged the fisheries agreements at the Court. In fact, in February 2018, the Court published another resolution in which it stated that a new agreement could not cover the waters adjacent to the Western Sahara, although the fisheries industry and Morocco claimed that a considerable portion of the benefits of the agreement accrued to the population of the disputed territory. Consequently, the EU attempted to broaden the negotiations by consulting representatives of all the relevant territories. However, the Polisario declined to participate. This did not stop the EC and the Moroccan government from implementing a new agreement, after consultations with as many local representatives as seemed possible under the circumstances.

When it came to a vote in the EP, the Greens demanded that once again the text should be referred to the European Court of Justice (The Greens/EFA, 2019). On February 2, 2019, however, Parliament finally gave consent to a new four-year agreement, allowing about $130 \mathrm{EU}$ vessels for a sum of $€ 208 \mathrm{~m}$ to fish in Moroccan waters, including the Western Sahara territory. $415 \mathrm{MEPs}$ voted for the deal, with 189 against and 49 abstentions, despite vociferous protests by NGOs (EUObserver, 2019). The majority of the EP maintained that the agreement would not constitute the recognition of Moroccan sovereignty over Western Sahara. On March 4, the Council gave its consent with a similar statement.

This case study shows unambiguously that, over the past decade, both political contestation and the number of actors dealing with negotiations has risen continuously. The role of the EP has been crucial in this respect. The involvement of the Court is particularly noteworthy. And yet the public salience of the issue remains limited. A search of newspapers indexed in Nexis from 
1998-2017 showed that FPAs were discussed only in very few articles. Most of the debate occurs in specialized internet publications, often those published by NGOs.

\subsection{Mauritania}

In terms of volume and financial contribution, the agreement with Mauritania is the EU's most important SFPA. The renewal of the protocols thus attracted particular attention from the fishing industry, NGOs and, more recently, the EP itself. It did so only in the last decade, however. The 2012 renegotiation of the 2006 protocol turned out to be riven with conflict, and it resulted in a compromise that was rejected by the EU fishing industry and their allies in EU institutions.

The normative discourse established during the runup to the 2013 CFP reform and the empowerment of the EP strongly influenced the decision-making process. It gave particular clout to scientific evaluations which argued that previous protocols had caused depleted fish stocks, to the detriment of the Mauritanian fishing sector (Oceanic Développement, 2011). In May 2011, the EP adopted a resolution which demanded that the EU fleet should only target the surplus of fish-that is, the sustainable quantity above the level that was reached by Mauritanian fishers. The EP further argued that the most valuable species, octopus, should be excluded from the new protocol (Corten, 2014, p. 3).

Negotiations with Mauritania began in June 2011 and quickly became protracted, as the Mauritanians seized on the new mood and ramped up their demands. They were supported by vocal European and African NGOs (Nagel \& Gray, 2012). The fishing industry warned the EC that a new protocol in line with Mauritanian conditions would not be commercially viable (Corten, 2014, p. 4). In July 2012, days before the expiration of the old protocol, the EC presented a provisional extension of the 2006 protocol, pending consent of the EP. It went very far in meeting Mauritanian demands and reflected the philosophy of the 2012 Green Paper.

As soon as the provisional text became known, protests began. The EU fisheries industry lambasted the agreement as commercially useless (EP, 2013b). Subsequently, most EU vessels effectively ceased fishing in the Mauritanian EEZ. And yet most member states supported the result, even some with fishing interests in Mauritania. They were presumably responding to pressure by NGOs in their countries (Corten, 2014, p. 7). Another factor influencing member states' support for the agreement was their interest in stabilizing Mauritania given ongoing unrest in Mali at the same time (Interview with EC Official). Thus, the Council signed the protocol in December 2012 and agreed to its provisional application, until the EP gave its consent.

In February 2013, the EP Committee on Development recommended consent. However, three months later, the PECH, under its Spanish rapporteur Gabriel Mato, recommended that the EP withhold its consent since the protocol made no economic sense (EP, 2013c). In the ensuing months, Spain initiated a strong campaign to convince MEPs to vote against the agreement (Jönsson, 2012). However, numerous NGOs lobbied the parliamentarians, and in the end they easily carried the day (EP, 2013b). In October 2013, the EP voted for the protocol with 467 votes in favor and 154 votes against, with the latter coming especially from the European People's Party. This was signed in November.

The whole process underlined the layered politicization' of the external dimension of the CFP. The parliamentarization of SFPA negotiations mobilized new actors who were able to politicize the process. This gave rise to serious conflicts within all three major EU organs. However, an evaluation of the subsequent media coverage of these developments shows that public engagement with the issue was still rather limited. While there was polarization and mobilization in the layers of narratives and rules, the low degree of salience remained.

A similar pattern was observable in the next round of negotiations which ended, in November 2015, with a new protocol coming into effect. In the early stages of the negotiation of this protocol, the EP produced a resolution on the external dimension of the CFP which promoted the Mauritania deal as a potential model (EP, 2016). The resolution and the report on which this was based (EP, 2015) was strongly influenced by the results of a conference of the Long Distance Advisory Committee (LDAC), an advisory body established by the Council and $E C$ in 2007. The LDAC combines representatives of industry, NGOs, European states and member states. In its recommendations, the Committee states that:

The essence of the partnership between African countries and the European Union should be the joint promotion of sustainable environmental, social and economic development based on transparency and the participation of non-governmental stakeholders, especially the professionals who depend on fishing for their livelihood. The conservation of resources and the protection of the marine environment are essential in order to guarantee sustainable fishing for future generations" (LDAC, 2015).

This was reflected in the protocol, despite strident protests by the fishing industry (North Africa Post, 2015). In addition to its strong normative content, the SFPA again contained a provision which obliged Mauritania to publish all agreements with other states or private entities which were entitled to access to Mauritanian waters. This was to ensure that other agreements with lower standards would not undermine the objectives of the EU SFPA and allow for other states to out-compete the EU. As a result, Russia launched a complaint at the World Trade Organization, opening another arena of contestation (EP, 2013b).

Overall, however, the process was less conflict-prone than the earlier renegotiation. The protocol passed 
through the EP with a comfortable margin, although it was strenuously denounced by critical NGOs (AEFJN, 2016). This probably reflects the fact that civil society groups were more embedded in the process, while parliament was more frequently consulted. In this sense, the polarization and the mobilization of the rules dimension became less pronounced.

One reason for the vote might have been the refugee crisis of 2015. This drew attention to the fact that Mauritania is a transit country, and that it has a long common border with troubled Mali. This provides another opening for contested meanings that different actors will attach to the agreement. The impending renegotiation might become yet another partially politicized process.

\section{Conclusions}

Politicization is a concept that has been developed to account for the increasing but often diffuse contestation of global and European governance. In their comprehensive study on the politicization of European integration in the past 50 years, Hutter et.al. argued that there was no consistent pattern or trend towards the politicization of EU politics. Instead, they observed significant variation across time and country, which they termed 'punctuated politicization' (2016, p. 280). However, their research concentrated on the big turning points and crises of European integration. It is thus quite reasonable to expect that, in a less prominent arena such as the CFP and its external dimension, this pattern would be even more pronounced.

As this article has demonstrated, some elements of politicization can indeed be identified in the CFP, but they are far from consistent and they have not yet mobilized a broader public. To account for this incomplete pattern, the concept of 'layered politicization' has been employed. Two decisive elements shape this 'layered' politicization: the increasing prominence of a normative discourse on fisheries policy that was institutionalized with the reform of the CFP (layer of narratives) and the parliamentarization of the CFP as a consequence of the Lisbon Treaty (layer of rules). Parliamentarization allowed for many more actors to gain access to the decision-making process. Such actors include expert committees and civil society groups. Crucially, these actors now have a much better chance to influence policy outcomes. External fisheries policy has become a contested policy field, and the EP has become a core arena. Faced with a divided council, its clout is considerable.

This also allows the EC to use the EP in a similar way as US trade negotiators use Congress: as potential a vetoplayer in a two-level game with counterparts in international negotiations, but also as a potentially legitimizing actor. Consequently, negotiations have also become more complicated, with some fisheries protocols lapsing and EU counterparts becoming increasingly upset about the intrusiveness of the agreements. While many NGOs still see the EU's fisheries policy as exploitative, their in- clusion in the process has made their arguments less strident. The incomplete politicization of the external dimension of the CFP has had the same effects that were identified for cases of comprehensive politicization: less efficiency, but more legitimacy. Overall, then, the use of a more fine-grained concept of politicization might enable future research to more systematically link specific forms of politicization to particular policy outcomes.

\section{Acknowledgments}

The author acknowledges the comments of two anonymous reviewers and of participants of a March 2017 workshop in Gothenburg as well as a panel at EUSA/Denver, CO in May 2019.

\section{Conflict of Interests}

The author declares no conflict of interests.

\section{References}

AEFJN. (2016). EU fishing deals in Africa: Scraping the bottom of the barrel. AEFJN.com. Retrieved from http://aefjn.org/en/eu-fishing-deals-in-africascraping-the-bottom-of-the-barrel

Court of Justice of the European Union. (2016, December 21). The association and liberalisation agreements concluded between the EU and Morocco are not applicable to Western Sahara [Press release]. Luxembourg: Court of Justice of the European Union. Retrieved from curia.europa.eu/jcms/ $\mathrm{jcms} / \mathrm{p} 1 \_268842 / \mathrm{fr}$

Client Earth. (2018). British public overwhelmingly supports greater fisheries protection. ClientEarth. Retrieved from https://www.clientearth.org/britishpublic-support-fisheries-protections-brexit

Corten, A. (2014). EU Mauretania fisheries partnership in need of more transparency. Marine Policy, 49(1), $1-11$.

Daw, T., \& Gray, T. (2005). Fisheries science and sustainability in international policy: A Study of failure of the EU's common fisheries policy. Marine Policy, 29(3), 189-197.

De Bièvre, D., \& Poletti, A. (2019). Explaining varying degrees of politicization of EU trade agreement negotiations: On necessary and sufficient conditions. Paper prepared for EUSA Conference, Denver, Colorado, USA.

De Vries, C. E., \& Hobolt, S. (2015). Issue entrepreneurship and multiparty competition. Comparative Political Studies, 48(9), 1159-1185.

De Wilde, P., Leupold, A., \& Schmidtke, H. (2016). Introduction: The differentiated politicisation of European governance. West European Politics, 39(1), 3-22.

Dür, A., \& Mateo, G. (2016). Insiders versus outsiders: Interest group politics in multilevel Europe. Oxford and New York, NY: Oxford University Press. 
EUObserver. (2019). EU parliament backs Western Sahara fish deal with Morocco. EUObserver. Retrieved from https://euobserver.com/tickers/144148

European Commission. (2009). Green paper: Reform of the CFP (COM(2009)163 final). Brussels: European Commission. Retrieved from https://eurlex.europa.eu/LexUriServ/LexUriServ.do?uri=COM: 2009:0163:FIN:EN:PDF

European Commission. (2010). Commission staff working document: Synthesis of the consultation on the reform of the common fisheries policy (SEC(2010)428 final). Brussels: European Commission. Retrieved from ec.europa.eu/fisheries/sites/fisheries/files/docs/ body/sec\%282010\%290428_en.pdf

European Parliament. (2012). Resolution of 22 November on the external dimension of the common fisheries policy (P7_TA(2012)0461). Brussels: European Parliament. Retrieved from europarl.europa.eu/ sides/getDoc.do?type=TA\&reference=P7-TA-20120461\&language $=E N \&$ ring $=A 7-2012-0290$

European Parliament. (2013a). EU-Morocco fisheries partnership agreement: Protocol setting out fishing opportunities and financial contributions (P7_TA-PROV(2013)0522). Brussels: European Parliament. Retrieved from http://www.europarl.europa. eu/document/activities/cont/201312/20131211 ATT75868/20131211ATT75868EN.pdf

European Parliament. (2013b). Library briefing: EUMauritania fisheries agreements (130562REV2). Brussels: European Parliament. Retrieved from http://www.europarl.europa.eu/RegData/ bibliotheque/briefing/2013/130562/LDM_BRI \%282013\%29130562_REV2_EN.pdf

European Parliament. (2013c). Committee report tabled for plenary, 1st reading/single reading (2012/0258(NLE)). Brussels: European Parliament. Retrieved from https://oeil.secure.europarl.europa. eu/oeil/popups/summary.do?id=1271291\&t=e\&l=en

European Parliament. (2015). Report on common rules in respect of application of the external dimension of the CFP, including fisheries agreements (A8-0052/2016). Brussels: European Parliament. Retrieved from www.europarl.europa.eu/doceo/ document/A-8-2016-0052_EN.pdf

European Parliament. (2016). European Parliament resolution of 12 April 2016 on common rules in respect of application of the external dimension of the CFP, including fisheries agreements (P8_TA(2016)0110). Retrieved from http://www.europarl.europa.eu/doceo/ document/TA-8-2016-0110_EN.html?redirect

European Parliament, \& Council of the European Union. (2013). Regulation (EU) No. 1380/2013 of the EP and of the Council of 11 December 2013 on the common fisheries policy. Luxembourg: Publications Office of the European Union. Retrieved from eur-lex. europa.eu/legal-content/EN/TXT/PDF/?uri=CELEX: 32013R1380\&from $=E N$

Faber, G., \& Orbie, J. (Eds.). (2007). European Union trade politics and development: Everything but arms unravelled. London: Routledge.

Gegout, C. (2016). Unethical power Europe? Something fishy about EU trade and development policies. Third World Quarterly, 37(12), 2192-2210.

Greene, D., \& Cross, J. P. (2015). Unveiling the political agenda of the European Parliament plenary: A topical analysis. In Proceedings of the ACM Web Conference (pp. 1-10). Oxford: ACM Web Science. Retrieved from https://insight-centre.org/sites/ default/files/publications/unveiling_the_political_ agenda_of_the_european_parliament.pdf

Griffin, L. (2013). Good governance, scale and power: A case study of North Sea fisheries. New York, NY: Routledge.

Hooghe, L., \& Marks, G. (2009). A postfunctionalist theory of European integration: From permissive consensus to constraining dissensus. British Journal of Political Science, 39(1), 1-23.

Hooghe, L., \& Marks, G. (2018). Cleavage theory meets Europe's crises: Lipset, Rokkan, and the transnational cleavage. Journal of European Public Policy, 25(1), 109-135.

Hurrelmann, A., Gora, A., \& Wagner, A. (2015). The politicization of European integration: More than an elite affair? Political Studies, 63(1), 43-59.

Hutter, S., Kriesi, H.-P., \& Grande, E. (2016). Politicizing Europe: Integration and mass politics. Cambridge: Cambridge University Press.

Jönsson, H. (2012). The EU-Moroccan fisheries partnership agreement: A process-tracing case study of the potential extension in 2011. Lund: Lund University Department of Political Science.

Long Distance Advisory Committee. (2015). Recommendations: IDAC conference on external dimension of the CFP Las Palmas de Gran Canaria, 16-17 September 2015. Madrid: Long Distance Advisory Committee. Retrieved from http://chil.me/download-file/ eff5940d-9283-4220-b6ae-0e73267faa30/en-finalrecommendations-conference-ldac-ed-cfp

Lövin, I. (2012). Silent seas: The fish race to the bottom. Rothersthorpe: Paragon Publishing.

Lowndes, V., \& Roberts, M. (2013). Why institutions matter: The new institutionalism in political science. Houndmills Basingstoke: Palgrave.

Nagel, P., \& Gray, T. (2012). Is the EU's FPA with Mauretania a genuine partnership or exploitation by the EU? Ocean \& Costal Management, 56(2), 6-34.

North Africa Post. (2015). Mauritania signs "win-win" fishing agreement with EU. The North Africa Post. Retrieved from http://northafricapost.com/8383mauritania-signs-win-win-fishing-agreement-witheu.html

Oceanic Développement. (2010). Convention specifique $n^{\circ}$ 26: evaluation ex post du protocole actuel d'accord de partenariat dans le domaine de la peche entre L'union Européenne et le Royaume du Maroc [Ex-post evaluation of protocol of the fisheries partnership 
agreement between the EU and Morocco]. Concarneau: Oceanic Développement. Retrieved from http://www.fishelsewhere.eu/files/dated/2012-0305/evaluation-app-maroc-2010.pdf

Oceanic Développement. (2011). Convention specifique $n^{\circ}$ 30: Evaluation ex-post du protocole actuel d'accord de partenariat dans le domaine de la peche entre L'union Europeénne et la Mauritanie. Etude d'impact d'un possible futur protocole d'accord [Expost evaluation of protocol of the fisheries partnership agreement between the EU and Mauritania. Impact study of future agreement]. Concarneau: Oceanic Développement. Retrieved from www.asktheeu.org/de/request/164/response/556/ attach/html/2/Evaluation\%20study\%20Mauritania \%20public\%20version.pdf.html

Passos, R. (2016). The external powers of the European Parliament. In P. Eeckhout \& M. Lopez-Escudero (Eds.), The European Union's external action in times of crisis (pp. 85-128). Oxford: Hart.

Payne, D. C. (2000). Policy-making in nested institutions: Explaining the conservation failure of the EU's common fisheries policy. Journal of Common Market Studies, 38(2), 303-324.

Penas Lado, E. (2016). The common fisheries policy: The quest for sustainability. Oxford: Wiley-Blackwell.

Rixen, T., \& Viola, L. A. (2015). Putting path dependence in its place: Toward a taxonomy of institutional change. Journal of Theoretical Politics, 27(2), 301-323.

Rosén, G. (2016). A match made in heaven? Explaining patterns of cooperation between the Commission and the European Parliament. Journal of European Integration, 38(4), 409-424.

Schmidtke, H. (2016). The differentiated politicization of European tax governance. West European Politics, 39(1), 64-83.

Streeck, W., \& Thelen, K. (2005). Beyond continuity: Institutional change in advanced political economies. Oxford: Oxford University Press.

The Greens/EFA. (2019, February 12). EU-Morocco fisheries agreement violates international humanitarian law [Press release]. Retrieved from https:// www.greens-efa.eu/en/article/press/eu-moroccofisheries-agreement-violates-internationalhumanitarian-law

Wakefield, J. (2016). Reforming the common fisheries policy. Ashgate: Elgar.

Witbooi, E. (2008). The infusion of sustainability into bilateral fisheries agreements with developing countries: The European Union example. Marine Policy, 32(4), 669-679.

Witbooi, E. (2012). Fisheries and sustainability: A legal analysis of $E U$ and West African agreements. Leiden: Nijhoff.

Zimmermann, H. (2016). Balancing sustainability and commerce: The EU and the negotiation of fisheries partnership agreements. Journal of European Public Policy, 24(1), 135-155.

Zürn, M. (2014). The politicization of world politics and its effects: Eight propositions. European Political Science Review, 6(1), 47-71.

\section{About the Author}

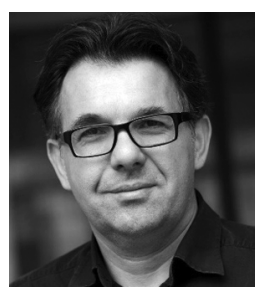

Hubert Zimmermann is Professor for International Relations at Philipps University Marburg, Germany. He has held positions at Düsseldorf University (Germany) and Cornell University (USA), and graduated from the European University Institute in Florence. His current research interests focus on international security, global financial and monetary policy, the EU (in particular foreign economic and security policy), foreign military intervention, and transatlantic relations. 